\title{
The Many Faces of Iranian Modernity
}

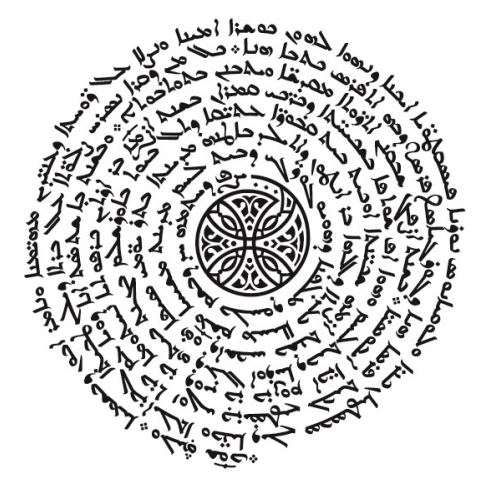




\section{The Modern Muslim World}

8

Series Editorial Board

$\begin{aligned} \text { Marcia Hermansen } & \text { Martin Nguyen } \\ \text { Hina Azam } & \text { Joas Wagemakers } \\ \text { Ussama Makdisi } & \end{aligned}$

Advisory Editorial Board

$\begin{aligned} \text { Talal Asad } & \text { Tijana Krstic } \\ \text { Khaled Abou El Fadl } & \text { Ebrahim Moosa } \\ \text { Amira Bennison } & \text { Adam Sabra } \\ \text { Islam Dayeh } & \text { Armando Salvatore } \\ \text { Marwa Elshakry } & \text { Adam Talib } \\ \text { Rana Hisham Issa } & \end{aligned}$

This series will provide a platform for scholarly research on Islamic and Muslim thought, emerging from any geographical area and dated to any period from the 17 th century until the present day. 


\section{The Many Faces of Iranian Modernity}

Sufism and Subjectivity in the Safavid and Qajar Periods

Robert Landau Ames

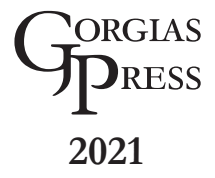


Gorgias Press LLC, 954 River Road, Piscataway, NJ, 08854, USA

www.gorgiaspress.com

Copyright (C) 2021 by Gorgias Press LLC

All rights reserved under International and Pan-American Copyright Conventions. No part of this publication may be reproduced, stored in a retrieval system or transmitted in any form or by any means, electronic, mechanical, photocopying, recording, scanning or otherwise without the prior written permission of Gorgias Press LLC.

2021

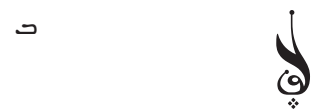

ISBN 978-1-4632-4237-4

\section{Library of Congress Cataloging-in-Publication Data}

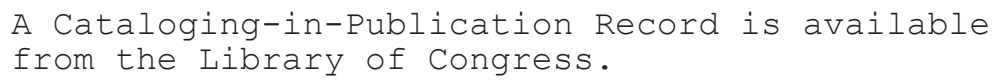

Printed in the United States of America 